\title{
Penerapan PSAK No. 45 Tentang Pelaporan Keuangan Entitas Nirlaba Pada Lksa Panti Asuhan Nurul Husna Patrang
}

\author{
Amalia Virgi Effendy ${ }^{1}$, Norita Citra Y ${ }^{2}$, Gardina Aulin Nuha ${ }^{3}$ \\ 1,2,3Program Studi Akuntansi Fakultas Ekonomi, Universitas Muhammadiyah Jember, Jawa Timur, Indonesia
}

\author{
A R T I C L E I N F O \\ Article history: \\ Received 19 May 2019 \\ Received in revised form \\ 16 June 2019 \\ Accepted 15 July 2019 \\ Available online 26 August \\ 2019 \\ Kata Kunci: \\ PSAK 45, Laporan \\ Keuangan \\ Keywords \\ PSAK 45, Financial Report
}

\begin{abstract}
A B S T R A K
Laporan keuangan adalah alat untuk menganalisis kinerja keuangan lembaga yang dapat memberikan informasi tentang laporan posisi keuangan, kegiatan, dan arus kas, sehingga berfungsi untuk pengambilan keputusan oleh manajemen. Penelitian ini sangat penting bagi Panti Asuhan LKSA Nurul Husna Patrang dalam penyusunan laporan keuangan karena merupakan pedoman untuk penyusunan laporan keuangan yang benar dan sesuai dengan PSAK No. 45. Penelitian ini bertujuan untuk menerapkan laporan keuangan LKSA Panti Asuhan Nurul Husna Patrang sesuai dengan PSAK No. 45. Aplikasi ini sangat dibutuhkan oleh institusi karena selain menjadi pedoman juga sebagai alat pertanggungjawaban atas kinerja yang dilakukan kepada donor, masyarakat dan institusi. Penelitian ini menggunakan metode kualitatif dan teknik pengumpulan data dilakukan dengan wawancara, observasi dan dokumentasi. Hasil penelitian ini menunjukkan bahwa penyusunan laporan keuangan di Panti Asuhan LKSA Nurul Husna tidak sesuai dengan PSAK No.45 karena laporan yang disiapkan oleh lembaga, yaitu laporan perawatan dan pelaporan. Sehingga aplikasi laporan keuangan dihasilkan sesuai dengan PSAK No. 45 yang terdiri dari laporan posisi keuangan, laporan aktivitas dan laporan arus kas.
\end{abstract}

A B S T R A C T

Financial statements are a tool for analyzing financial performance of institutions that can provide information about financial position reports, activities and cash flows, so that it functions for decision making by management. This research is very important for the LKSA Nurul Husna Patrang Orphanage in the preparation of financial statements because it is a guideline for preparing financial statements that are correct and in accordance with PSAK No. 45. This study aims to apply the financial statements of the LKSA Nurul Husna Patrang Orphanage in accordance with PSAK No. 45. This application is very much needed by the institution because in addition to being a guideline also as a means of accountability for the performance carried out to donors, communities and institutions. This study uses qualitative methods and data collection techniques are carried out by interview, observation and documentation. The results of this study indicate that the preparation of financial statements on the LKSA Nurul Husna Orphanage is not in accordance with PSAK No. 45 because of the reports prepared by the institution, namely the care and reporting reports. So that the application of financial statements is produced in accordance with PSAK No. 45 which consists of financial position reports, activity reports and cash flow statements.

\footnotetext{
Corresponding author.

E-mail addresses: VigriAmalia11@gmail.com (Amalia Vigri Effendy)
} 


\section{Pendahuluan}

Ikatan Akuntan Indonesia ( IAI ) menerbitkan pernyataan standar akuntansi keuangan yang mengatur pencatatan laporan keuangan pada organisasi nirlaba yaitu PSAK No. 45 yang terdiri dari laporan posisi keuangan, laporan aktivitas, laporan arus kas dan catatan atas laporan keuangan. Dengan terbitnya standar akuntansi keuangan tersebut diharapkan dapat diterapkan pada seluruh organisasi nirlaba yang berada di Indonesia, mengingat dengan pencatatan yang diterapkan organisasi nirlaba berbeda dengan pencatatan organisasi bisnis, sehingga standar tersebut sangat diperlukan. Laporan keuangan yang disusun sesuai dengan PSAK No. 45 dapat mengetahui berapa jumlah dana yang diterima dan jenis kegiatan apa saja yang dilakukan. Oleh karena itu, transparansi dan akuntabilitas sangat diperlukan dalam penyusunan laporan keuangan panti agar dapat memberikan informasi yang relevan dan dapat diandalkan kepada donatur.

Di Indonesia, kini organisasi nirlaba yang berbentuk yayasan telah bergerak dalam berbagai bentuk kegiatan, area pelayanan yang semakin luas, serta ukuran dari organisasi yang dapat dikatagorikan sebagai raksasa dalam dunia bisnis. Bahkan beberapa yayasan dalam dunia pendidikan ternyata mempunyai asset bernilai milyaran rupiah. Sejalan dengan perkembangan masyarakat yang semakin kritis, mereka menuntut diterapkannya good governance atau tata kelola organisasi yang baik pada yayasan. Maka dari itu, prinsip transparansi dan akuntabilitas harus dibuktikan. (Nainggolan, 2005) (Kurniawan, 2016)

Organisasi nirlaba dalam memperoleh danaya untuk aktivitas di peroleh dari sumbangan yang di kordinir oleh pengelola yayasan, untuk itu yayasan harus transparansi dalam pengelolaah keuangan untuk di laporkan kepada penyumbang. Bentuk transparan tersebut dengan melaporkan keuangan yang di kelolanya dengan menggunakan standar yang di terapkan di Indonesia yaitu dengan berpedoman PSAK Nomor 45 tentang “organisasi nirlaba”( Jumaiyah, 2019)

Organisasi nirlaba memiliki karakteristik yang sangat berbeda dibandingkan dengan organisasi bisnis. Karakteristik khusus yang mendasari perbedaan tersebut menurut PSAK 45 tentang pelaporan keuangan organisasi keuangan nirlaba terutama terletak pada cara organisasi nirlaba memperoleh sumberdaya yang dibutuhkan untuk melakukan berbagai aktivitas operasinya. Organisasi nirlaba memperoleh sumberdaya dari sumbangan para penyumbang yang tidak mengharapkan pembayaran kembali atau pengembalian manfaat ekonomi yang sebanding dengan jumlah sumberdaya yang diberikan (Ikatan Akuntan Indonesia,2012) (Ismatullah ,2018).

Organisasi nirlaba atau organisasi Non Profit merupakan suatu organisasi yang bertujuan untuk menghasilkan kemaslahatan masyarakat bukan bertujuan untuk menghasilkan laca atau profit melainkan lebih fokus ke tujuan sosial dan lingkungan. Organisasi nirlaba meliputi panti asuhan, sekolah negeri maupun swasta, rumah sakit dan lain sebagainya. Dalam organisasi, perancangan sangatlah penting karena untuk mengantisipasi keadaan yang terjadi dimasa akan datang. Dari setiap organisasi mempunyai perencanaan yang berbeda - beda dilihat dari tingkat ketidakpastian dan kestabilan lingkungan yang dihadapi. Jika tingkat ketidakpastian dan kestabilan tersebut semakin tinggi maka perencanaan yang direncanakan harus semakin baik dan stabil.

Muhammadiyah merupakan sebuah gerakan islam yang melaksanakan dakwah amar ma'ruf nahi mungkar dengan maksud dan tujuan menegakkan dan menjunjung tinggi agama islam sehingga terwujud masyarakat islam yang sebenar - benarnya. LKSA Panti Asuhan Nurul Husna Patrang merupakan Amal Usaha Muhammadiyah (AUM ) yang berdiri pada tanggal 03 April 2014 dibawah naungan Majelis Pelayanan Sosial Muhammadiyah cabang patrang - Jember. Dari lembaga ini dapat mengembangkan tingkat pendidikan dan skill terhadap anak di Indonesia.

Dibawah naungan Muhammadiyah, banyak lembaga sosial yang didirikan di Indonesia, berbagai macam lembaga diantaranya panti asuhan yatim, panti jompo, balai kesehatan sosial, panti wreda, panti cacat netra, santunan, BPKM, rehabilitasi cacat dan pondok pesantren. LKSA Panti Asuhan Nurul Husna Patrang merupakan salah satu lembaga sosial muhammadiyah yang bergerak pada bidang sosial diwilayah kabupaten Jember. Organisasi nirlaba ini memiliki komitmen sejak awal berdiri, yaitu untuk memberikan jasa dan pelayanan. Hal tersebut telah dibuktikan bahwa adanya perkembangan dalam lembaga sosial yang dinaunginya. Saat ini terdapat beberapa lembaga sosial yang didirikan dikabupaten Jember. Setiap lembaga juga memiliki tujuan untuk mengembangkan skill terhadap anak bangsa terutama pada daerah sekitarnya.

LKSA Panti Asuhan Nurul Husna merupakan lembaga yang digunakan sebagai sarana untuk meningkatkan pendidikan anak - anak yatim piatu. Adanya panti asuhan ini karena banyaknya anak anak yang dibawah umur yang terlantar di daerah Jember, dikarenakan kondisi perekonomian orang tuanya yang kurang mampu untuk memenuhi kebutuhan setiap harinya, sehingga melalui lembaga ini dapat meringankan beban atau dapat mencukupi kebutuhannya sehari - hari. Selain memberikan 
kebutuhan - kebutuhannya, lembaga juga memberikan materi - materi yang dapat mengembangkan prestasi anak. Untuk menjalankan dan mengembangkan lembaga yang lebih baik maka membutuhkan suplai dana. Oleh karena itu pengelola dari lembaga harus mampu memberikan informasi yang baik terhadap para penyumbang yaitu berupa laporan keuangan. Dan pihak manajemen juga harus memikirkan bagaimana bentuk penyajian laporan keuangan yang dicatat kepada pihak internal terutama pada pihak eksternal agar para penyumbang percaya dan tidak menghentikan dana terhadap lembaga yang dikelolanya.

Dalam penilaian kinerja organisasi nirlaba, sangat diperlukan suatu pertanggung jawaban pelaporan keuangan yang terjadi pada organisasi tersebut. Akuntabilitas publik merupakan suatu kewajiban yang harus dilakukan kepada pihak pemegang amanah untuk melakukan pertanggungjawaban pelaporan penyajian dan pengungkapan dari berbagai aktivitas dan kegiatannya yang menjadi tanggungjawab kepada pihak yang memberikan amanah. "Akuntansi merupakan suatu pengukuran, pengelompokan, penjabaran dan memberikan kepastian mengenai informasi yang diperlukan oleh pihak yang membutuhkan dalam pengambilan keputusan."

Pada awal berdirinya LKSA Panti Asuhan Nurul Husna Patrang sudah menyusun laporan keuangan akan tetapi laporan keuangan yang disusun tersebut masih belum relevan dan andal. Laporan keuangan yang disusun oleh lembaga hanya laporan pengasuhan dan pembangunan. Pencatatannya masih dicatat secara manual, sehingga akan berdampak pada lembaga yaitu akan kehilangan kepercayaan dan dana masuk pada panti akan mengalami fluktuatif maupun penurunan. Karena masyarakat menginginkan untuk mengetahui bagaimana gambaran pengelolaan dana tersebut baik donasi yang diterima secara langsung maupun tidak secara langsung. Masyarakat juga sebagai pengguna laporan keuangan dapat menilai kinerja yang dilakukan oleh lembaga. Berikut grafik penerimaan dana masuk pada LKSA Panti Asuhan Nurul Husna Patrang bulan juli hingga oktober tahun 2018.

Berdasarkan uraian latar belakang diatas, dengan mengingat pentingnya pelaporan keuangan pada panti asuhan maka penulis tertarik melakukan penelitian yang berjudul "Penerapan PSAK No. 45 tentang Pelaporan Keuangan Entitas Nirlaba pada LKSA Panti Asuhan Nurul Husna Patrang".

Menurut Bastian Indra ( 2010 ) bertanggung jawab terhadap keuangan pada suatu organisasi adapun standar akuntansi yang berlaku untuk menyusun keuangan dari segala aktivitas pada organisasi sektor publik, standar tersebut yaitu PSAK No. 45 yang berkaitan dengan pelaporan keuangan organisasi nirlaba. Dilihat dari karakteristik organisasi nirlaba sangat berbeda dengan organisasi bisnis. Kunci perbedaan yang terlihat terletak pada cara memperoleh sumber daya yang dibutuhkan untuk melakukan segala aktivitas operasional organisasi. Perolehan sumber daya pada organisasi sektor publik dari para penyumbang, dari hal tersebut jarang sekali dan bahkan tidak pernah terjadi pada organisasi bisnis.

Organisasi nirlaba merupakan suatu organisasi yang tidak bertujuan untuk menghasilkan profit atau laba melainkan lebih fokus ke tujuan dibidang sosial dan lingkungan. Ribka Chenly (2013) menyatakan bahwa organisasi nirlaba atau organisasi non profit adalah suatu organisasi yang berkepentingan untuk mendukung suatu isu atau perihal didalam menarik perhatian publik untuk suatu tujuan yang tidak komersil, tanpa ada hal - hal yang memiliki tujuan mencari laba ( moneter ). Organisasi nirlaba meliputi yayasan, sekolah negeri maupun swasta, masjid, rumah sakit dan lain sebagainya.

Karakteristik entitas nirlaba sangatlah berbeda dengan entitas bisnis. Perbedaan utama dilihat dari perolehan sumber daya yang dibutuhkan untuk melakukan berbagai aktivitas operasinya. Perolehan sumber daya dari pemberi sumber daya pada entitas nirlaba tidak mengharapkan pembayaran kembali atau manfaat ekonomi sebanding dengan jumlah sumber daya yang diberikan. Dari karakteristik tersebut jarang dan bahkan tidak pernah terjadi pada entitas bisnis, misalnya penerimaan sumbangan.

Laporan keuangan disiapkan oleh setiap perusahaan untuk dapat memberikan informasi yang berguna bagi para pemakai laporan, terutama untuk dijadikan sebagai dasar pertimbangan dalam proses pengambilan keputusan. Laporan keuangan merupakan produk akhir dari serangkaian proses pencatatan dan pengikhtisaran data transaksi bisnis, dimana seorang akuntan diharapkan mampu untuk mengorganisir seluruh data Akuntansi (Erica, 2018).

Laporan keuangan merupakan bagian utama dalam menganalisis suatu perusahaan. Menurut PSAK No. 45 ( revisi 2011 ) Tujuan paling utama dalam penyusunan laporan keuangan adalah untuk menyediakan informasi yang relevan dalam memenuhi kepentingan pemberi sumber daya yang tidak mengharapkan pembayaran kembali, anggota, kreditur dan berbagai pihak lain yang sebagai sumber daya bagi entitas nirlaba.

Laporan keuangan merupakan media atau alat untuk mengukur kondisi keuangan suatu perusahaan. Dalam penelitian ini, analisis laporan keuangan digunakan untuk mengetahui apakah aktiva perusahaan dapat mencover kebutuhan jangka pendek.Hasil penelitian diperoleh berdasarkan analisis terhadap laporan keuangan tahun 2012,2013,2014 dan 2015 yang menggunakan empat rasio keuangan (likuiditas, solvabilitas, profitabilitas dan aktivitas) (Zannati,2016). 
laporan keuangan adalah menyediakan informasi yang menyangkut posisi keuangan, kinerja serta perubahan posisi keuangan suatu perusahaan yang bermanfaat bagi sejumlah besar pemakainya dalam pengambilan keputusan ekonomi. Artinya, laporan keuangan merupakan alat untuk memperoleh informasi mengenai posisi keuangan dan hasil operasi yang telah dicapai oleh suatu perusahaan. Informasi tersebut nantinya akan digunakan sebagai bahan pertimbangan dalam pengambilan keputusan, baik oleh management perusahaan maupun pihak ekstern perusahaan (Dwi, 2016)

Laporan keuangan pada dasarnya adalah hasil dari proses akuntansi yang dapat digunakan sebagai alat untuk berkomuniksi dengan pihak yang berkepentingan dengan kondisi keuangan dan hasil operasi perusahaan. Kondisi keuangan dan hasil operasi perusahaan yang tercermin dalam laporan keuangan perusahaan merupakan hasil akhir dari kegiatan akuntansi perusahaan yang bersangkutan. Informasi tentang kondisi keuangan dan hasil operasi perusahaan sangat berguna bagi berbagai pihak, baik pihak yang ada di dalam perusahaan maupun pihak yang berada di luar perusahaan. Informasi yang berguna misalnya tentang kemampuan perusahaan untuk melunasi hutang-hutang jangka pendek, kemampuan perusahaan dalam membayar bunga dan pokok pinjaman, dan keberhasilan perusahaan dalam meningkatkan besarnya modal sendiri. Bentuk informasi yang digunakan untuk mengetahui keadaan keuangan perusahaan adalah laporan keuangan. Laporan keuangan disusun untuk menyediakan informasi yang menyangkut posisi keuangan, kinerja dan perubahan posisi keuangan suatu perusahaan yang bermanfaat bagi sejumlah besar pemakai dalam pengambilan keputusan ekonomi (Wahyuning, 2015).

\section{Metode}

Didalam penelitian pasti membutuhkan sebuah data yang saling berhubungan dengan permasalahan yang akan diteliti. Menurut Ribka Chenly ( 2013 ) data merupakan suatu keterangan yang didapat oleh peneliti melalui referensi yang digunakan untuk menganalisis permasalahan yang terjadi dan mencari alternatif yang sesuai. Menurut Ribka ( 2013 ) data dibedakan menjadi 2 ( dua ) jenis yaitu data kualitatif dan kuantitatif, dimana data kualitatif merupakan data yang tidak berupa jumlah atau angka, seperti : wawancara, rekaman, dokumentasi dan lain - lain. Sedangkan untuk data kuantitatif merupakan data yang berupa jumlah atau angka, seperti : pengukuran. Tetapi dalam penelitian ini, jenis penelitian yang diterapkan oleh peneliti yaitu data kualitatif. Tujuan dari penerapan data kualitatif untuk menyajikan suatu data yang valid dan lengkap berkenaan dengan lembaga yang dimaksudkan dan bertujuan untuk mengklasifikasi dan mendeskripsi masalah yang diteliti pada fenomena yang sering terjadi disuatu lembaga.

Penelitian ini menggunakan 2 ( dua ) jenis sumber data yaitu data primer dan sekunder yang diambil dari objek penelitian. Perolehan data dengan menggunakan data primer yaitu wawancara secara langsung kepada ketua, sekretaris dan bendahara LKSA Panti Asuhan Nurul Husna. Sedangkan perolehan data dengan menggunakan data sekunder diperoleh dari buku - buku dan dokumen - dokumen yang terkait pada LKSA Panti Asuhan Nurul Husna. Teknik analisis data yang digunakan terdapat 4 (Empat) macam yang sesuai dengan pendapat Huberman dan Miles : Pengumpulan data, Reduksi data, penyajian data dan kesimpulan.

\section{Hasil dan pembahasan}

\section{Laporan Keuangan LKSA Panti Asuhan Nurul Husna Patrang}

LKSA Panti Asuhan Nurul Husna Patrang menyusun 2 ( dua ) macam laporan keuangan yaitu laporan pembangunan dan pengasuhan. Didalam kedua laporan tersebut hanya mencatat keluar masuknya dana. Laporan pembangunan yang disusun hanya mencatat keluar masuknya dana untuk kegiatan pembagunan pada panti, sedangkan pencatatan laporan pengasuhan mencatat keluar masuknya dana untuk kegiatan yang berkaitan dengan anak asuh pada panti seperti biaya makanan, minuman, pakaian dan sekolah. Sehingga setiap terjadinya transaksi dicatat dalam laporan tersebut dan dilaporkan setiap bulannya. Dari kedua laporan dicatat oleh 2 bendahara dan adapun pembagiannya yaitu bendahara 1 hanya mencatat laporan pengasuhan, sedangkan bendahara 2 mencatat laporan pembangunan dan dari kedua laporan tersebut diserahkan atau dilaporkan pada bendahara umum. Sehingga dari pembagian tugas pencatatan laporan pada masing-masing transaksi yang terjadi, baik dalam pengasuhan maupun pembangunan akan dapat mempermudah dalam melakukan pencatatan laporan keuangan lembaga.

Laporan keuangan merupakan sebuah catatan informasi keuangan suatu perusahaan pada satu periode untuk menilai kinerja lembaga (IAI, 2011). Laporan keuangan yang sesuai dengan PSAK 45 yaitu Laporan Posisi Keuangan, Laporan Aktivitas dan Laporan Arus Kas maupun disertakan Catatan Atas Laporan Keuangan (CALK). 
Berikut merupakan contoh laporan keuangan yang sesuai dengan PSAK 45 yaitu laporan posisi keuangan, laporan aktivitas dan laporan arus kas pada LKSA Panti Asuhan Nurul Husna Patrang.

Tabel 1. Laporan Posisi Keuangan LKSA Panti Asuhan Nurul Husna Patrang

\section{LKSA PANTI ASUHAN NURUL HUSNA PATRANG \\ LAPORAN POSISI KEUANGAN}

TAHUN 2018

\begin{tabular}{|c|c|c|}
\hline \\
\hline \multirow{2}{*}{\multicolumn{3}{|c|}{$\begin{array}{l}\text { Nama Akun } \\
\text { Aset Lancar }\end{array}$}} \\
\hline & & \\
\hline Kas dan setara kas & $\mathrm{Rp}$ & 118.909 .125 \\
\hline Kas dibank & $\mathrm{Rp}$ & 95.870 .000 \\
\hline Perlengkapan & $\mathrm{Rp}$ & 490.000 \\
\hline Total Aset Lancar & $\mathrm{Rp}$ & 215.269 .125 \\
\hline \multicolumn{3}{|l|}{ Aset Tetap } \\
\hline Tanah & $\mathrm{Rp}$ & 850.000 .000 \\
\hline Bangunan & $\mathrm{Rp}$ & 1.250 .067 .050 \\
\hline Akumulasi penyusutan bangunan & $-R p$ & 62.503 .353 \\
\hline Kendaraan & $\mathrm{Rp}$ & 15.000 .000 \\
\hline Akumulasi penyusutan kendaraan & $-R p$ & 1.875 .000 \\
\hline Peralatan & $\mathrm{Rp}$ & 66.529 .000 \\
\hline Akumulasi penyusutan peralatan & $-R p$ & 11.711 .625 \\
\hline Total Aset Tetap & $\mathrm{Rp}$ & 2.105.506.073 \\
\hline TOTAL ASET & $\mathbf{R p}$ & 2.320 .775 .198 \\
\hline \multicolumn{3}{|l|}{ KEWAJIBAN } \\
\hline Hutang & $\mathrm{Rp}$ & 7.760 .000 \\
\hline Total Kewajiban & $\mathrm{Rp}$ & 7.760 .000 \\
\hline \multicolumn{3}{|l|}{ ASSET NETTO } \\
\hline Aset netto tidak terikat & $\mathrm{Rp}$ & 68.432 .375 \\
\hline Aset Netto terikat temporer & $\mathrm{Rp}$ & 214.779 .125 \\
\hline Aset netto terikat permanen & $\mathrm{Rp}$ & 2.029.803.698 \\
\hline Total Aset Netto & $\mathrm{Rp}$ & 2.313.015.198 \\
\hline TOTAL ASET NETTO DAN KEWAJIBAN & Rp & 2.320 .775 .198 \\
\hline
\end{tabular}

Tabel 2. Laporan Arus Kas LKSA Panti Asuhan Nurul Husna Patrang

\section{LKSA PANTI ASUHAN NURUL HUSNA PATRANG \\ LAPORAN AKTIVITAS \\ TAHUN 2018}

Perubahan Aset Netto Tidak Terikat

Pendapatan :

Sumbangan $\quad$ Rp 156.845 .500

Pendapatan $\quad$ Rp $\quad 25.200 .000$

JUMLAH PENDAPATAN $\quad$ Rp 182.045 .500

Beban :

Beban pengasuh

Beban pengasuhan

Rp $\quad 5.500 .000$

Beban konsumsi

Rp $\quad 39.394 .000$

Beban Gaji

Rp $\quad 31.850 .000$

Rp $\quad 3.000 .000$ 


\begin{tabular}{llr} 
Beban STNK & $\mathrm{Rp}$ & 265.000 \\
Beban transportasi & $\mathrm{Rp}$ & 6.600 .000 \\
Beban peralatan & $\mathrm{Rp}$ & 636.000 \\
Beban infaq & $\mathrm{Rp}$ & 1.630 .000 \\
Beban lain - lain & $\mathrm{Rp}$ & 900.000 \\
Jumlah Beban & $\mathrm{Rp}$ & 89.775 .000 \\
\hline
\end{tabular}

Kenaikan / Penurunan Aset Netto Tidak Terikat

Rp $\quad 13.586 .625$

Aset Netto Tidak Terikat Awal Tahun

$\mathrm{Rp}$

82.019 .000

Aset Netto Tidak Terikat Akhir Tahun

$\mathrm{Rp}$

68.432 .375

Kenaikan / Penurunan Aset Netto Terikat Temporer

Rp $\quad 92.870 .500$

Aset Netto Terikat Temporer Awal Tahun

$\mathrm{Rp}$

121.908 .625

Aset Netto Terikat Temporer Akhir Tahun

$\mathrm{Rp}$

214.779 .125

Kenaikan / Penurunan Aset Netto Terikat Permanen

$\mathrm{Rp}$

431.963 .698

Aset Netto Terikat Permanen Awal Tahun

Rp $\quad 1.597 .840 .000$

Aset Netto Terikat Permanen Akhir Tahun

$\mathrm{Rp}$

2.029.803.698

Total Aset Netto

$\mathbf{R p}$

2.313.015.198

Tabel 3. Laporan Arus Kas LKSA Panti Asuhan Nurul Husna Patrang

\section{LKSA PANTI ASUHAN NURUL HUSNA PATRANG \\ LAPORAN ARUS KAS \\ TAHUN 2018}

\begin{tabular}{|c|c|c|}
\hline $\begin{array}{l}\text { Saldo Awal } \\
\text { Kas dan setara kas } \\
\text { Kas dibank }\end{array}$ & $\begin{array}{l}\mathrm{Rp} \\
\mathrm{Rp}\end{array}$ & $\begin{array}{l}37.450 .625 \\
84.458 .000 \\
\end{array}$ \\
\hline $\begin{array}{l}\text { Arus kas masuk dari aktivitas operasi : } \\
\text { Sumbangan dari donatur } \\
\text { Pendapatan } \\
\text { Terima pinjaman } \\
\text { Penambahan kas dari BSM }\end{array}$ & $\begin{array}{l}\mathrm{Rp} \\
\mathrm{Rp} \\
\mathrm{Rp} \\
\mathrm{Rp}\end{array}$ & $\begin{array}{c}156.845 .500 \\
25.200 .000 \\
600.000 \\
19.000 .000 \\
\end{array}$ \\
\hline Total Arus kas masuk dari aktivitas operasi & $\mathrm{Rp}$ & 201.645 .500 \\
\hline $\begin{array}{l}\text { Arus kas keluar dari aktivitas operasional : } \\
\text { Beban pengasuh } \\
\text { Beban pengasuhan } \\
\text { Beban konsumsi } \\
\text { Beban gaji } \\
\text { Beban STNK } \\
\text { Beban transportasi } \\
\text { Beban peralatan } \\
\text { Beban infaq } \\
\text { Beban lain - lain } \\
\text { Penyetoran kas pada BSM }\end{array}$ & $\begin{array}{l}\mathrm{Rp} \\
\mathrm{Rp} \\
\mathrm{Rp} \\
\mathrm{Rp} \\
\mathrm{Rp} \\
\mathrm{Rp} \\
\mathrm{Rp} \\
\mathrm{Rp} \\
\mathrm{Rp} \\
\mathrm{Rp}\end{array}$ & $\begin{array}{c}5.500 .000 \\
39.394 .000 \\
31.850 .000 \\
3.000 .000 \\
265.000 \\
6.600 .000 \\
636.000 \\
1.630 .000 \\
900.000 \\
19.000 .000 \\
\end{array}$ \\
\hline Total arus kas keluar & $\mathrm{Rp}$ & 108.775 .000 \\
\hline $\begin{array}{l}\text { Kenaikan kas } \\
\text { Saldo Kas Akhir Tahun }\end{array}$ & & $\begin{array}{r}92.870 .500 \\
\mathbf{1 4 . 7 7 9 . 1 2 5} \\
\end{array}$ \\
\hline
\end{tabular}


Hasil penelitian ini menunjukkan bahwa LKSA Panti Asuhan Nurul Husna Patrang belum menerapkan PSAK No. 45 tentang Pelaporan Keuangan Entitas Nirlaba pada laporan keuangannya, laporan yang disusun oleh lembaga yaitu laporan pengasuhan dan pembangunan yang hanya mencatat pemasukkan maupun pengeluaran kas pada transaksi yang terjadi. Pencatatan laporan keuangan pengasuhan pada lembaga yang hanya berkaitan dengan transaksi atau aktivitas pengasuhan baik berupa penerimaan kas maupun pengeluaran kas dan penyusunan laporan keuangan tersebut disusun oleh khusus bendahara 1 bagian pengasuhan, sedangkan pencatatan laporan keuangan pembangunan mencatat segala aktivitas atau transaksi yang hanya berkaitan dengan pembangunan baik berupa penerimaan maupun pengeluaran kas yang disusun oleh bendahara 2 bagian pembangunan. Penyusun laporan keuangan antara pengasuhan dan pembangunan berbeda, untuk laporan pengasuhan disusun oleh bendahara 1 bagian pengasuhan dan laporan pembangunan disusun oleh bendahara 2 bagian pembangunan. Selanjutnya pada setiap akhir bulan, dari masing-masing bendahara melaporkan hasil laporan keuangan lembaga kepada bendahara umum lembaga. Segala bentuk penerimaan kas dari donatur baik melalui secara langsung maupun transfer tidak langsung diberikan pada bendahara umum, tetapi kas tersebut masih berada ditangan bendahara baik bendahara pengasuhan maupun pembangunan. Hal tersebut karena untuk mengklaim jika ada keperluan mendesak atau dadakan.

Apabila melihat kondisi dari laporan keuangan yang disusun oleh LKSA Panti Asuhan Nurul Husna Patrang, lembaga sangatlah memerlukan suatu penyusunan laporan keuangan yang baik dan sesuai dengan standar pelaporan keuangan. Sehingga nantinya laporan keuangan yang disusun mencerminksn aktivitas operasional lembaga yang sebenarnya dan laporan keuangan yang disusun lebih mudah dipahami oleh para pengguna baik lembaga, masyarakat dan donatur serta memberikan gambaran pada masa depan dari lembaga untuk memastikan jasanya dapat terus disalurkan dan dimanfaatkan oleh masyarakat. Adapun kendala dalam proses pertanggungjawaban keuangan pada lembaga yaitu belum adanya sumber daya manusia yang ahli dalam penyusunan laporan keuangan sesuai dengan standar akuntansi.

Penyusunan pelaporan keuangan agar sesuai dengan standar akuntansi yang berlaku di Indonesia, yaitu PSAK No.45, maka peneliti menerapkan laporan keuangan berdasarkan transaksi atau data lembaga yang didapatkan serta didapat dari pengamatan terhadap objek penelitian baik secara langsung maupun tidak. Penerapan pelaporan keuangan pada LKSA Panti Asuhan Nurul Husna yang sesuai dengan standar akuntansi diantaranya : Laporan Posisi Keuangan, Laporan Aktivitas, Laporan Arus Kas dan Catatan Atas Laporan Keuangan (CALK).

\section{Simpulan dan saran}

Berdasarkan data dari pembahasan hasil penelitian yang telah dilakukan di LKSA Panti Asuhan Nurul Husna Patrang dapat disimpulkan bahwa laporan keuangan yang disusun sebelumnya masih bersifat sederhana. Proses pencatatan laporan keuangan yang digunakan yaitu laporan pengasuhan dan pembangunan, bentuk laporan keuangan hanya mencatat keluar dan masuknya dana sehingga belum sesuai dengan standar yang mengatur laporan keuangan organisasi nirlaba, yaitu PSAK 45. Informasi yang disajikan dari laporan keuangan saat ini masih belum memadai untuk menghasilkan informasi keuangan yang lengkap dan belum bisa memenuhi kebutuhan informasi keuangan dari para donatur atau penyumbang dana. Sehingga perlu adanya penerapan laporan keuangan yang sesuai dengan standar untuk menjadikan sebagai referensi bagi lembaga.

Sesuai dengan penelitian yang dilakukan di LKSA Panti Asuhan Nurul Husna Patrang, peneliti menyarankan kepada lembaga untuk menyusun laporan keuangan yang sesuai dengan PSAK No.45 sehingga dapat menghasilkan laporan keuangan yang efektif maupun efisien dan dapat memenuhi kebutuhan informasi yang lengkap bagi para donatur atau penyumbang dana. Laporan keuangan yang disusun sesuai dengan PSAK No. 45 yaitu laporan Posisi Keuangan, Laporan Aktivitas dan Laporan Arus kas yang dilengkapi dengan Catatan Atas Laporan Keuangan (CALK).

\section{Daftar Rujukan}

Bastian, Indra. 2006. Akuntansi Sektor Publik. Erlangga. Yogyakarta.

Bastian, Indra. 2010. Akuntansi Sektor Publik : Suatu Pengantar. Penerbit Erlangga. Yogyakarta. 
Dwi, Kurnia. (2016). Analisis Laporan Keuangan Dalam Mengukur Kinerja Perusahan Pada Pt. Ricky Kurniawan Kertapersada (Makin Group) Jambi . Jurnal Valuta Vol 2 No 2, Oktober 2016, 190-207 ISSN : 2502-1419

Erica, Denny. (2018). Analisa Rasio Laporan Keuangan Untuk Menilai Kinerja Perusahaan PT Kino Indonesia Tbk . Jurnal Ecodemica, Vol. 2 No. 1 April 2018

Ikatan Akuntan Indonesia ( IAI ). 2009. Laporan Arus Kas. Pernyataan Standar Akuntansi Keuangan No. 2 ( Revisi 2015 ). DSAK-IAI:Jakarta.

Ikatan Akuntan Indonesia ( IAI ). 2011. Pelaporan Keuangan Entitas Nirlaba. Pernyataan Standar Akuntansi Keuangan No. 45 (Revisi 2011). DSAK-IAI:Jakarta.

Ismatullah, Ismet. (2018). Transparansi Dan Akuntabilitas Dana Masjid Dalam Pemberdayaan Ekonomi Ummat. Jurnal Ilmiah Ilmu Ekonomi ISSN 20886969] Vol.6 Edisi 12, Mar 2018

Jumaiyah. (2019). Implementasi Pernyataan Standar Akuntansi Keuangan No 45 Pada Panti Asuhan AlHuda Ridwaniyah . Jurnal Akuntansi \& Ekonomi Fe. Un Pgri Kediri Vol. 4 No. 2, Maret 2019 ISSN: 2541-0180

Kurniawan, Aceng. (2016). Perancangan Sistem Akuntansi Keuangan untuk Menunjang Kualitas Laporan Keuangan pada Mi Miftahul Falah . Jurnal STAR - Study \& Accounting Research | Vol XIII No.2 2016

Ribka, Chenly. 2013. Penerapan Laporan Keuangan Organisasi Nirlaba Berdasarkan PSAK No 45 pada Gereja BZL. Jurnal Emba. Manado.

Wahyuning, Nur. (2015). Analisis Laporan Keuangan Sebagai Alat Untuk Menilai Kinerja Keuangan Pt Pelabuhan Indonesia Iii Surabaya . Jurnal Akuntansi dan Pendidikan, Vol.4 No.2, Oktober 2015

Zannati, Rachma.(2016). Analisis Laporan Keuangan Pt. Gatari Sebagai Dasar Pertimbangan Pemberian Kredit Modal Kerja Pada Pt.Bank Dk . Jurnal Riset Manajemen dan Bisnis Vol.1, No.2,Oktober 2016 : 81 - 92 ISSN 2527 - 7502 